\title{
ISLAMIC REGULATIONS AND ISLAMIC BANK MARGINS: AN EMPIRICAL INVESTIGATION INTO ASEAN COUNTRIES
}

\author{
Fatin Nur Hidayah Taib Khan ${ }^{1}$, Nurhafiza Abdul Kader Malim² and \\ Tajul Ariffin Masron ${ }^{3}$ \\ ${ }^{1}$ Universiti Sains Malaysia, Malaysia, fatinnurhidayah93@gmail.com \\ ${ }^{2}$ Universiti Sains Malaysia, Malaysia, fizanur@usm.my \\ ${ }^{3}$ Universiti Sains Malaysia, Malaysia, tams@usm.my
}

\begin{abstract}
This paper examines the impact of Islamic regulations on Islamic bank margins in ASEAN countries, utilising the fixed-effect method. The sample consists of 27 Islamic banks in Malaysia, Indonesia, Singapore and Thailand covering the period 2009 to 2017. The results suggest that Islamic regulations, such as the Islamic regulatory framework and Shari'ah supervisory board, are negatively associated with Islamic bank margins. These results have important policy implications for regulators, indicating that they should impose a separate regulatory framework for Islamic banks and bank managers to increase the number of Shari'ah scholars on the Shari'ah board in lowering Islamic bank margins. Overall, the findings suggest that Islamic banks should adopt regulations that should follow Shari'ah requirements, as they help to lower the cost of financial intermediation. As for the other control variables, only the Lerner index has a positive and significant impact on ASEAN Islamic bank's margin. Therefore, appropriate policies are necessary to foster competition in Islamic banks.
\end{abstract}

Keywords: Bank margins, Regulations, ASEAN countries, Islamic banks.

JEL classification: C33; G21; G28; L51.

Article history:

Received : October 7, 2020

Revised : January 13, 2021

Accepted : January 19, 2021

Available online : February 28, 2021

https://doi.org/10.21098/jimf.v7i1.1327 


\section{INTRODUCTION}

\subsection{Background}

The global financial crisis of 2007 severely affected the banking system, causing bankruptcy in leading banks and resulting in unemployment and low investment in the banking system. One of the contributing factors was inefficiency in the regulating banking frameworks. For instance, relaxation in regulations encouraged financial institutions to create highly instruments known as collateralised debt obligations $(\mathrm{CDOs})^{1}$ (Krugman, 2009). Therefore, policymakers and regulators expressed concern about the role of regulations in the banking industry and the role they may have played in the crisis and subsequent recovery (Alam et al., 2018; Bouheni et al., 2014).

Interestingly, the crisis affected the conventional banking system more severely than its Islamic counterpart (Hasan \& Dridi, 2010; Bourkhis \& Nabi, 2011; Olson \& Zoubi, 2017). One plausible reason for this is that the contracts utilised by Islamic banks are based on profit-loss sharing (PLS), also known as equitybased financing, non-profit-loss sharing (non-PLS), or debt-based financing. PLS prohibits debts at higher interest rates, and played an essential role during the global financial crisis (Boukhatem \& Moussa, 2018). For example, Islamic banks are not influenced by CDOs, as these are due to the shortcomings of interest rates (riba) (Alam et al., 2018). Nevertheless, Islamic banks do not fully apply PLS contracts, as these are mostly based on tangible assets, which could impose additional risk (Dar \&^ Presley, 2000). Islamic banks mainly operate under cost-plus contracts (Murabahah).

Although both conventional and Islamic banking systems are exposed to risks such as liquidity risk, credit risk, and exchange rate risk, Islamic banks are likely to suffer more severely because risk transfer is not allowed in the system in which they operate (Alam et al., 2018). Nevertheless, the distinctive nature of Islamic bank operations makes them susceptible to additional risks, such as displaced commercial risk ${ }^{2}$, which conventional banks do not face (Toumi et al., 2018). Hence, the approach to reducing risk employed by conventional banks is not suitable for Islamic ones, suggesting the importance of regulatory frameworks in Islamic banks. In general, such banks are governed by a regulatory framework implemented by conventional banks. However, Solé (2007) argues that the regulatory authorities of conventional banks may be unfamiliar with Islamic bank supervision. Moreover, the differences in Islamic bank theory and practice compared to conventional banks could lead to concerns in proposing a uniform regulatory framework for Islamic banks. Furthermore, Alexakis and Tsikouras (2009) state that conventional banks' regulatory framework could be inappropriate for Islamic ones. Therefore, this raises an interesting debate on the importance of Islamic banks having a separate regulatory framework to conventional ones.

1 Collateralised debt obligations (CDOs) are a structured financial product backed by a pool of assets (mortgages, loans or bonds) (Buffet, 2016).

2 Risk causes banks to yield profits earned to provide customers with an appropriate rate of return and prevent them from withdrawing their capital and depositing it in conventional banks. "yield profits earned" not clear 
Tongurai and Vithessonthi (2020) highlight that regulatory changes in the banking sector are critical in preventing bank failures. Interestingly, the ASEAN banking sector has undergone post-crisis regulatory and supervisory changes to strengthen capital requirements, activity restrictions, market discipline and official supervision of financial institutions (Lee \& Park, 2009). Alam (2014) states that regulations are necessary to protect depositors from risks related to deposits placed in banks. Depository banks play an intermediary role between borrowers and lenders, recognising that costly bank intermediation services are for society from the margins. The margins are gauged by the differences between lending and deposit rates, which measure the cost of intermediation for society (Poghosyan, 2013). Indirectly, bank margins are important in ASEAN countries with regard to sources of external funding, which largely depend on bank financing.

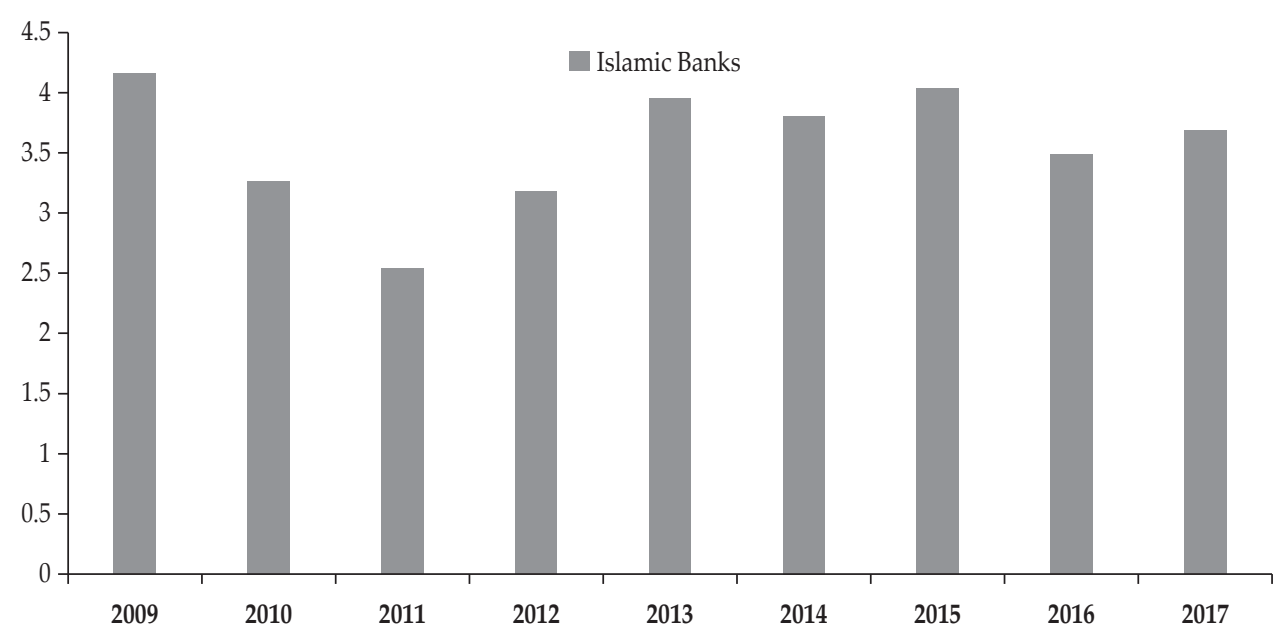

Source: Authors calculations

Figure 1.

Islamic Bank Margins by Year

Figure 1 presents the average Islamic bank margins in ASEAN countries from 2009 to 2017, showing a high level of margins, ranging from $2.5 \%$ to $4 \%$. A high level of interest margins is closely associated with banking system inefficiency, which is transferred to bank customers by charging high interest rates (Barajas, 1999). It is pertinent to understand whether the ASEAN banking system's regulatory framework helps Islamic banks to lower their margins. However, Alam et al. (2018) highlight that Islamic banks adopt regulations similar to conventional ones, which are not effective in catering for their unique risks. However, as yet there is no set of regulatory frameworks that govern Islamic banks, meaning they have to rely on those of conventional banks (Alam, 2013). Therefore, a question arises as to whether the implementation of such a framework would influence the efficiency of the banking system. 
Alam et al. (2018) stress that Islamic banks do indeed require a separate set of regulations to perform better. Moreover, several studies have emphasised that there is a lack of a well-defined and adequate regulatory and supervisory framework to govern Islamic banks in accordance with Shari'ah (Hassan et al., 2017). There is clearly a large body of literature on the role of regulations in the performance and efficiency of Islamic banks (Alam, 2013; Bitar et al., 2018; Mohd Noor et al., 2020; Wan Ibrahim \& Ismail, 2020), but there are literature focusses on the margins of Islamic banks. For instance, Alam (2013) conducted a study on the relationship between banking regulations and the efficiency and risk-taking behaviour of Islamic banks. Bitar et al. (2018) examined the role of the Basel III regulatory framework on the efficiency of Islamic and conventional banks, finding a negative relationship between the capital requirements proposed and Islamic bank efficiency. This implies that greater capital requirements would impede the effectiveness of the banking system. The findings of previous studies have prompted us to analyse the role of Islamic regulations on Islamic bank margins in ASEAN countries. Most existing studies on regulation have focused on bank performance and efficiency rather than bank margins, applying the regulation measurements suggested by Barth et al. (2001, 2006, 2013), without considering different approaches to the regulation of the Islamic banking sector.

\subsection{Objective}

This paper investigates the effect of Islamic regulations on the margins of Islamic banks in ASEAN countries. To the best of our knowledge, very few studies have explored this topic; for example, Alam et al. (2018), who only covered GCC countries and South/Southeast Asia. This study focuses on ASEAN countries, with the aim to extend the literature and explore how regulation of Islamic banks affects their margins, to provide useful suggestions for policymakers to achieve efficiency in the banking system. Second, the paper also contributes to the debate on separate Islamic bank regulations in a dual banking system. The literature only focuses on the impact of banking regulations in one system, rather than a dual one. Despite the essential role of regulations in Islamic bank efficiency and performance, there is very limited research on financial intermediation efficiency. Furthermore, although several studies have investigated the effect of regulations on bank margins, most of these have focused on cross-country or single country data from developed economies. Moreover, the period of study is from 2009 to 2017, which covers the post-crisis period. This period could provide better understanding of regulations in the Islamic banking system.

The remainder of the paper is organized as follows. Section 2 elaborates on the relevant literature concerning the impact of bank regulation on bank margins, while Section 3 describes the variables employed in the study and outlines the methodology used to measure the determinants of bank margins. Section 4 presents the descriptive statistics of the sample data and analyses the empirical results. Section 5 concludes the paper. 


\section{LITERATURE REVIEW}

\subsection{Background Theory}

In theoretical terms, the modelling framework for understanding the determinants of bank margins was introduced by Ho and Saunders (1981). This model initially constituted four variables: bank size, the degree of risk aversion, the uncertainty rate and the market structure. It suggests that a high level of bank margins is related to large banks, an increase in the degree of risk aversion, higher interest rates and a larger market structure. The model was then extended and modified by several researchers, including Allen (1988), Angbazo (1997), Maudos and Fernández De Guevara (2004), Carbó Valverde and Rodríguez Fernández (2007), Entrop et al. (2015), and Birchwood et al. (2017). For example, Allen (1988) includes the heterogeneity of the loan, while Angbazo (1997) extends the model by introducing credit risk. Subsequently, Maudos and Fernández De Guevara (2004) included operating costs, while Carbó Valverde and Rodríguez Fernández (2007) included bank specialisation in order to gauge the relationship between market power and bank margins. Entrop et al. (2015) incorporated maturity transformation and Birchwood et al. (2017) extended the model by including regulation variables.

As for banking regulation and bank margins, there is no specific theory that discusses the relationship between them. The existing theory of banking regulations considers the relationship between them and efficiency. It can be viewed from two perspectives: i) the public interest view, and ii) the private interest view (Stigler, 1971; Peltzman, 1976). Public interest theory assumes that regulations are organised to improve social welfare. Hence, the group involved in this theory is limited to the government and is independent from private interest. This implies that the government will act in the public interest, which encourages efficiency and prevents banking failure. On the other hand, private interest theory assumes that regulations result from a power balance among various interest groups, including the government, companies, consumers, and community residents. In this theory, regulations are implemented to further the interests of the lobbying groups that control the regulatory process, instead of correcting market failures. Therefore, the private interest theory suggests that the involvement of various groups will indirectly force the relaxation of regulations, which will encourage risk-taking within the banking sector.

\subsection{Previous Studies}

Alam (2012) defines banking regulation as a framework that controls banks' creation, operation, and liquidation in an economy. The Banking Regulation and Supervision was established to help the banking sector authorities to improve the effectiveness of the banking system (Kale et al., 2015). The regulatory framework helps the system to alleviate excessive risks to its growth. Furthermore, several studies have found that banking regulations are associated with banking performance and efficiency (Chortareas et al., 2012; Barth et al., 2013). The GFC in 2007 pushed governments to continuously improve their regulatory rules over the banking sector. Basel Committee Banking Supervision (BCBS) introduced some regulations, known as Basel, in response to the global financial crisis. There have 
been three set of Basel; Basel I was introduced in 1998, followed by Basel II in 2008. Finally, Basel III was introduced as a revised version of the Basel II guidelines.

Basel I was introduced in 1988 to minimise the capital adequacy ratio at $8 \%$. During the introduction of the first Basel accord, the Group of Ten (G10) countries were among the first to implement the capital adequacy framework, with Basel I later implemented progressively by other countries around the world. Nevertheless, Basel I was not free from criticism. For instance, the capital adequacy framework only considers the sole risk of lending and does not give different weight to borrowers of differing quality. Therefore, the Basel II regulatory framework was introduced in 2004 as an extension of the regulations of minimal capital requirements in Basel I and came into force in 2006. Basel II was introduced to strengthen the regulatory framework, focusing on three pillars: capital level requirements, the process of supervisory review, and market discipline. Subsequently, in 2010 Basel III was introduced as an extended version of the Basel II framework. It includes liquidity requirements and leverage ratios (Boumediene, 2011).

This process raised interest among policymakers and regulators regarding the role of regulations and their impact on the banking system. To gauge their role, Barth et al. (2001) introduced the first dataset of regulation variables, comprising several types of survey such as banking activities, ownership, capital, internal management, requirements of external audit, liquidity and diversification requirements, deposit insurance schemes, information and accounting disclosures, institutional issues and supervision. The regulation variables were then constructed according to the answers from the surveys. Currently, there are five surveys. The datasets have been used widely by other researchers to investigate the effect of regulations on the performance and efficiency of banking institutions (Barth et al., 2006; Chortareas et al., 2012; Barth et al., 2013; Psillaki and Mamatzakis, 2017; Haque and Brown, 2017; Alam et al., 2018). However, few studies have been conducted on the effect of regulations on bank margins using the same datasets (Demirguc-Kunt et al. 2004; Poghosyan, 2013; Birchwood et al., 2017). Demirguc-Kunt et al. (2004) investigate the relationship between bank regulations, market structure, and institutional variables and financial intermediation costs. They provide evidence that tighter regulations on bank activities will increase such costs. In addition, Gelos (2006) investigated the determinants of interest rate spreads in Latin America and found that the factors contributing to their high spread in Latin America were regulatory requirements.

In 2011, Naceur and Omran examined the role of bank regulation, concentration, and financial and institutional development in bank margins in Middle Eastern and North African (MENA) countries. They concluded that there was a positive and significant impact of bank capitalisation and credit risk on bank margins. As for the regulatory variable, the reserve requirement was observed to positively and significantly affect bank performance. An increase in reserve requirements was associated with higher opportunity costs, which led banks to charge customers higher deposit rates.

In the following year, Chortareaset al. (2012) investigated the role of regulatory and supervisory policies on the performance and effectiveness of the banking system in 22 European Union countries over the period 2000-2008. They obtained results in favour of regulations; strengthening the restrictions on bank activities 
and official supervisory powers could enhance the efficiency of bank operations. The results obtained of supervisory power on bank margins according to Beck et al . (2006), with the authors claiming that the ability to monitor and discipline by supervisors led to a reduction in market failure and corruption connected to bank loans. Consequently, this improved the operation of banks as intermediaries.

On the other hand, Poghosyan (2013) found an insignificant impact of the restriction of securities, real estate, insurance and ownership activities on bank margins in low-income countries. In addition, the fraction entry denied has a positive relationship with bank margins. This implies that a higher level of denied bank entries will protect Islamic banks and enable them to increase their margins.

Birchwood et al. (2017) analysed the impact of regulation variables on bank interest margins in Central America and the Caribbean over the period 1998-2014, finding that the tighter the requirements on bank entry and the fewer the number of foreign banks in a country, the higher bank margins will be. In addition, an increase in the transparency variable enabled banks in both the Caribbean and Central America to narrow their margins. The negative results obtained could suggest that transparent bank financial statements will reduce the cost of monitoring and screening for lenders and increase resource allocation. Rahman et al. (2017) studied the relationship between capital regulation and financial intermediation costs in 32 Bangladesh banks from 2000 to 2014. High-level capital regulations caused bank margins to increase.

Lin and Chen (2018) examined the relationship between capital regulation and bank margins in the multiple shadow banking activity environment. They found that bank margins could be lowered by constricting bank capital requirements, as this would encourage the flow in multiple shadow banking activities. Furthermore, Huang et al. (2018) proposed a barrier cap option framework for bank interest margins under capital regulation. This framework option would enable weakening of the behaviour of bank spread when considering banks as liquidity providers. Their estimation results suggest that a high level barrier cap would lead to low bank margins due to a decrease in demand deposits.

In the following year, Cruz-García and Fernández De Guevara (2019) researched the impact of capital regulation and deposit insurance on bank margins from 2000 and 2014 in OECD countries. They conclude that the interest variables (capital requirement and deposit insurance) have a positive impact on bank margins. The impact of the capital requirement variable on bank margins suggests that wellcapitalised banks will charge higher margins to overcome the cost and better withstand shocks. Meanwhile, the positive sign of the deposit insurance variable was due to the lower risk faced by depositors, resulting in lowering the interest rate on deposits, thereby enhancing the level of bank margins.

Although studies have been conducted on the impact of regulations on bank margins, few have focused on Islamic banks. Therefore, this creates plausible concern regarding the regulation of Islamic banks. The default framework for regulation and supervision was introduced by Basel Committee Banking Supervision (BCBS), known as Basel, and adopted by all banks around the world, including Islamic ones. However, there are no separate guidelines provided by Basel for Islamic banks which address their distinctive operation (Song and Oosthuizen, 2014). Accordingly, Islamic banks are required to comply with existing 
regulations similar to those of conventional banks, yet at the same time must ensure that their business operations and products are Shari'ah compliant (Alam et al., 2018). Unfortunately, due to the difference in the sources of Islamic funds, the regulation of Islamic banks may be more complicated than that of conventional banks. For example, Islamic banks are bound to suffer from displaced commercial risk, which is not faced by conventional banks. Hence, the adoption of a similar set of regulations to conventional banks may not be effective in addressing the risk faced by Islamic banks without making any distinction. This suggests that Islamic banks do indeed require a specific set of regulations. The existing Islamic bank regulatory framework differs significantly by country in terms of the structure and content of the regulations governing the operations of the banking system (Apaydin, 2018; Alsartawi, 2019). For example, Malaysian and Indonesian Islamic banks adopt a regulatory framework for both Islamic and conventional banks, but with separate guidelines for Islamic ones (Song and Oosthuizen, 2014).

Alam et al. (2018) also highlight issues related to the Shari'ah standards that are managed by the committee members of the Sharia Supervisory Board (SSB) of Islamic banks. They indicate that there might exist a problem involving the interpretation of the financial products allowed in Islamic banks by the board members. According to the Accounting and Auditing Organization of IFIs (AAOIFI) Governance standards, Islamic financial institutions are required to create an independent internal Shari'ah supervisory board consisting of at least three Shari'ah scholars (Grassa, 2013). Mollah and Zaman (2015) examined the relationship between such boards and bank performance from 2005 until 2014. They found that the Shari'ah supervisory board supervises the lending and risktaking activities of boards of directors and management to ensure a high level of banking system profitability. They also claim that the Shari'ah supervisory board is important to ensure that Islamic banks comply with Shari'ah standards. In addition, Hamza (2013) examined the model of Shari'ah governance employed in the Gulf Cooperation Council (GCC) and Malaysia. He concludes that the model used in the Malaysia banking system has a positive effect on Islamic banks' effectiveness and credibility.

However, few researchers have conducted studies on the role of regulations in the performance and efficiency of the Islamic banking system (Alam et al., 2018; Ibrahim, 2019; Wan Ibrahim \& Ismail, 2020). One example was Ibrahim (2019), who conducted empirical research on the effect of capital regulation on Islamic banks in 13 dual banking countries from 2000 to 2014. His results show that capital regulations are negatively associated with the profitability of Islamic banks. The stringent capital requirements imposed on Islamic banks will reduce their profitability.

Wan Ibrahim and Ismail (2020) examined the relationship between regulations and Islamic bank efficiency in Malaysia in the period from 2008 to 2013. They included activity restriction variables as regulation variables to test their effect on banks efficiency. Their findings suggest that the tighter the restriction on Islamic banking activities, the greater the efficiency achieved. In other words, the activities prohibited in Islamic banks by Shari'ah will help reduce moral hazard problems, thereby increasing the banking system's effectiveness in in Malaysia. Similarly, Mohd Noor et al. (2020) claim that activity restriction positively influences 
the effectiveness of the banking system. Their positive results show that such restrictions prevent the creation of complex structures that are hard to monitor. They conclude that stricter private monitoring and intervention by supervisory bodies could significantly enhance Islamic bank efficiency.

On the other hand, Alam et al. (2018) examined the effect of Islamic regulations on the performance of Asian and the Gulf Cooperation Council (GCC) Islamic banks from 2006 to 2015 by including different regulation measurements, in addition to the regulation variables proposed by Barth et al. (2013). They incorporated four variables, the Islamic regulatory framework, fundamental law, the Shari'ah supervisory board and national supervisory board, to test the impact of regulations on Islamic banks. The different set of measurement included Islamic banks with governance structures different to those of conventional banks, which follows Shari'ah principles. Alam et al.'s findings suggest that the Islamic regulatory variables tested were positively significant only in relation to Islamic bank performance in the Asian region. Apart from the regulatory framework that addresses the needs of capital, there are also regulation issues related to Shari'ah compliance managed by members of the Shari'ah supervisory board of Islamic banks (Alam et al., 2018). They found an insignificant impact of Shari'ah supervisory boards on the Islamic banking system's performance.

Although there has been research conducted on bank regulations on bank margins, there is limited research on the regulation of Islamic banks and bank margins in ASEAN countries. Islamic regulations are more complex than conventional ones as their implementation must be in line with Shari'ah principles. For instance, Islamic banks are susceptible to different risks that are more difficult to counter than in conventional banks. This suggests that Islamic banks require specific regulations to cater for the differences in their operations. This therefore creates plausible concern amongst policymakers concerning the regulations imposed on Islamic banks to maintain a low level of bank margins and low intermediation costs.

\section{METHODOLOGY}

\subsection{Data}

The banking data source was the FitchConnect database provided by Fitch Solutions, which reports financial statements from banks worldwide.

Most of the variables collected were in ratios, except for total assets, whose values are large and calculated in logarithm form. The Islamic regulation variables were taken from the annual reports of each bank each year. In addition, the macroeconomic data, the annual percentage growth rate of growth domestic products (GDP), and the inflation rate were collected from the World Development Indicators (World Bank, 2019). The sample comprised 28 Islamic banks, covering four ASEAN countries (Malaysia, Indonesia, Singapore and Thailand). However, the financial statement data for Islamic banks were only available until 2017. Hence, due to insufficient data on bank-specific factors, the data used in the study covered yearly bank-level data from the 2009-2017 period. Furthermore, the study focuses on the period after the crisis to investigate the impact of Islamic regulation of Islamic banks' margins. The crisis required the banking system to impose tighter 
regulations to overcome bank failures due to default risk. Therefore, the post-crisis period could emphasise the role of such regulation.

\subsection{Model Development}

The study model was developed from the work of Birchwood et al. (2017), who proposed an augmented Ho and Saunders (1981) model to measure the effect of regulations on bank margins. The empirical specification takes the following form:

$$
N F M_{i, j t}=\alpha+\beta_{1} B S_{i, j, t}+\beta_{2} I S_{i, j, t}+\beta_{3} M V_{i, j, t}+\beta_{4} I R_{i, j, t}+\varepsilon_{i, j, t}
$$

where the indexes of $i, j$ and $t$ represent country, bank and time. NFM represents bank margins as a dependent variable, while for the explanatory variables, $B S_{i j}$ is the bank-specific characteristics of bank $j$ in country $i$. The bank-specific variables are size, the degree of risk aversion, credit risk, liquidity and the management efficiency of a banking system. $I S_{i j}$ denotes the industry-specific variable that uses the Lerner index to reflect market power at the bank level in country $i$ at time t. $M V_{i j}$ represents the macroeconomic variables covering the growth of domestic produce and the inflation rate, which are included to consider the differences in the banking system across the sample countries and in interest rate risk. In terms of the regulatory variables, $I R_{i j}$ consists of the Islamic regulatory framework and Shari'ah supervisory board, and $\varepsilon_{i j}$ is the error term.

The Islamic regulatory framework is a dummy variable reflecting whether there is a separate regulatory framework specifically designed for Islamic banks (Alam et al., 2018). It takes a value of 1 if there does exist a separate framework, and 0 otherwise. Alam et al. (2018) found that the Islamic regulatory framework positively impacts bank performance, indicating that a separate regulatory framework for Islamic banks would also enhance performance. Therefore, the Islamic regulatory framework is expected tosignify positive findings on Islamic bank margins.

The second variable was that of Shari'ah supervisory board, which measures the number of Shari'ah scholars on the board (Alam et al., 2018). Such boards play an essential role in regulating Islamic bank operations according to Shari'ah principles (Mollah \& Zaman, 2015). The board members are tasked with supervising Islamic bank activities to ensure their compliance with Shari'ah. This paper proposes that the number of Shari'ah scholars in a bank, according to governance standards, could help impose appropriate regulations that could help lower Islamic bank margins, leading to the following expectation Shari'ah supervisory, which is a negative relationship with bank margins.

The bank-specific variables, such as bank size, benefit margins in terms of economies of scale, and reduced costs or economies of scope. The pioneering study on bank margins was based on Ho and Saunders (1981), and concluded that there was a a positive relationship between bank size and bank margins. Bank with higher margins tend to be larger, implying that banks operate on a significant scale of economies. However, some studies have obtained negative results, such as those of Maudos and Fernández De Guevara (2004) and Fungacova and Poghosyan 
(2009). Negative results directly imply that a reduction in costs is attributed to economies of scale.

Risk aversion is used to measure premium risk (Poghosyan, 2013); the proxy for risk aversion is the quotient of equity over total assets (Ho and Saunders, 1981; Poghosyan, 2013; Trinugrohoet al., 2014). Higher managerial risk aversion will increase interest margins, as proposed by Ho and Saunders (1981). Maudos and Fernández De Guevara (2004) found a positive influence of risk aversion on bank margins, as more risk-averse banks would charge higher margins. Therefore, a positive sign is expected.

Credit risk reflects the interest rate on loans, with higher interest rates charged on longer- term loans. Maudos and Fernández De Guevara (2004) claim that an increase in credit risk will increase bank margins due to higher lending activity, reflecting banks' ability to integrate risk. For example, banks will assign a high risk status to customers in relation to an increase in the financing rate, thereby leading to a high margin. Hence, the sign for the relationship between credit risk and bank margins is expected to be negative.

Interest rate risk was included in a few studies as a determinant of bank margins. This study employed the measurement of interest rate risk used by Birchwood et al. (2017); that is, the standard deviation of the monthly lending rate. The results show that bank margins are positively related to interest rate risk. A positive and significant result is expected for the relationship between interest rate risk and bank margins in this paper.

Liquidity measurement can capture liquidity mismatches between the assets and liabilities of a banking system (IMF, 2006). The ratio of total liquid assets to total assets is employed as a liquidity measurement proxy following DemirgucKunt et al. (2004). Liquid assets are assets that can be readily converted into cash. Following previous research, a positive sign is predicted. Banks with higher liquidity ratios will have low liquidity risk; therefore, higher margins are charged by banks as the opportunity cost of holding higher liquidity increases.

Another bank-specific indicator is management efficiency, which is calculated as the cost to income ratio, following Maudos and Solís (2009). The cost to income ratio expresses the ability of a bank to generate income in terms of operating costs, ignoring interest expenses. Banks with high unit costs have lower management efficiency, causing bank margins to fall (Maudos and Solís, 2009).

To measure the market-specific factor, the Lerner index was incorporated in this paper. The index is calculated as the ratio of the mark-up pricing of banking products to marginal costs (Meslier et al., 2017). It captures a bank's ability to set the price of output above its marginal cost (Ibrahim et al., 2018). The measurement of the Lerner index is as follows:

$$
\text { Lerner }_{i t}=\frac{\text { Price }_{i t}-M C_{i t}}{M C_{i t}}
$$

where Price $_{i t}$ is the price of the bank's $i$ output at time $t$. The price is measured as the ratio of total revenue to total assets. Total revenue is the sum of total interest income and the total of non-interest operating income. $M C_{i t}$ is the marginal cost of the total assets of bank $i$ at time $t$. The marginal cost is computed using the trans- 
logarithm of the total cost function with one output and three inputs (price of labour, price of capital and price of funds), following the methodology by Meslier et al. (2017). Maudos and Solís (2009) suggest a positive relationship between the Lerner index and bank margins, because banks with greater market power will increase their margins to exercise market conditions.

The macroeconomic variables that are usually applied are GDP and the inflation rate. Real per capita gross domestic product (GDP) growth is used as a proxy for opportunities since banks may respond to the business cycle by contracting loans during periods of recession and facilitating them during periods of expansion. The findings of Chortareas et al. (2012) show a negatively significant relationship between GDP and bank margins. Accordingly, in a favourable macroeconomic environment, banks are expected to have a low level of bank margins. This might reduce lending costs because of high economic activity, which negatively impacts bank margins.

Based on Poghosyan (2013), the rate of inflation was measured by changes in the consumer price index rate. An excessive inflation rate means banks experience high margins (Gelos, 2006; Beck \& Hesse, 2009). An increase in the inflation rate is associated with an increase in default risk, leading banks to charge a higher lending price and resulting in greater bank margins.

Table 1 presents a summary of the variables included in the study. Some factors were found to have an impact on bank margins in previous studies.

Table 1.

Descriptions of the Variables

\begin{tabular}{|c|c|c|c|}
\hline Variables & Proxy & Source & $\begin{array}{l}\text { Expected } \\
\text { sign }\end{array}$ \\
\hline \multicolumn{4}{|c|}{ Dependent Variable } \\
\hline $\begin{array}{l}\text { Net Financing } \\
\text { Margin }\end{array}$ & $\begin{array}{l}\text { Net financing income over average } \\
\text { earning assets. }\end{array}$ & FitchConnect & \\
\hline \multicolumn{4}{|c|}{ Independent Variables } \\
\hline \multicolumn{4}{|c|}{ I. Bank-specific Variables } \\
\hline Bank Size & $\begin{array}{l}\text { Natural logarithm of total assets } \\
\text { (Trinugroho et al., 2018). }\end{array}$ & FitchConnect & $+/-$ \\
\hline $\begin{array}{l}\text { Degree of Risk } \\
\text { Aversion }\end{array}$ & $\begin{array}{l}\text { Ratio of equity to total assets } \\
\text { (Poghosyan, 2013). }\end{array}$ & FitchConnect & + \\
\hline Credit Risk & $\begin{array}{l}\text { Ratio of loan loss reserves to gross } \\
\text { loans (Kasmidou et al., 2006). }\end{array}$ & FitchConnect & + \\
\hline Liquidity & $\begin{array}{l}\text { Ratio of total liquid assets to total } \\
\text { assets (Demirguc-Kunt et al., 2004). }\end{array}$ & FitchConnect & + \\
\hline $\begin{array}{l}\text { Management } \\
\text { Efficiency }\end{array}$ & $\begin{array}{c}\text { Cost to income ratio (Maudos \& } \\
\text { Solís, 2009). }\end{array}$ & FitchConnect & - \\
\hline \multicolumn{4}{|c|}{ II. Industry-Specific Variables } \\
\hline Lerner Index & $\begin{array}{c}\text { Ratio of the mark-up pricing of } \\
\text { banking products to marginal cost } \\
\text { (Meslier et al., 2017). }\end{array}$ & FitchConnect & + \\
\hline
\end{tabular}


Table 1.

Descriptions of the Variables (Continued)

\begin{tabular}{|c|c|c|c|}
\hline Variables & Proxy & Source & $\begin{array}{l}\text { Expected } \\
\text { sign }\end{array}$ \\
\hline \multicolumn{4}{|c|}{ III. Macroeconomic Variables } \\
\hline GDP Growth & $\begin{array}{l}\text { Annual percentage growth rate of } \\
\text { GDP (Chortareas et al., 2012). }\end{array}$ & Worldbank & - \\
\hline Inflation & $\begin{array}{l}\text { Changes in the consumer price } \\
\text { index (Poghosyan, 2013). }\end{array}$ & Worldbank & + \\
\hline Interest Rate Risk & $\begin{array}{c}\text { Standard deviation in the monthly } \\
\text { lending rate (Birchwood et al., } \\
\text { 2017). }\end{array}$ & $\begin{array}{l}\text { Worldbank \& own } \\
\text { calculations }\end{array}$ & + \\
\hline \multicolumn{4}{|l|}{ IV. Regulations } \\
\hline $\begin{array}{l}\text { Regulatory } \\
\text { Framework }\end{array}$ & $\begin{array}{l}\text { The regulatory framework } \\
\text { designed specifically for Islamic } \\
\text { banks (Alam et al., 2018). }\end{array}$ & Dummy variable & + \\
\hline $\begin{array}{l}\text { Shari'ah } \\
\text { Supervisory Board }\end{array}$ & $\begin{array}{c}\text { Number of Shari'ah scholars in each } \\
\text { bank in the country (Alam et al., } \\
\text { 2018). }\end{array}$ & Bank Annual Reports & - \\
\hline
\end{tabular}

\subsection{Method}

A wide variety of methods can be applied to determine the factors influencing bank margins. The most widely used of these is the Generalized Panel Method of Moments (GMM), a method which has been employed by various previous studies(Chortareas et al., 2012; Poghosyan, 2013; Lee and Isa, 2017; Bougatef and Korbi, 2018; Yanikkaya et al., 2018). However, the number of cross-sectional units used in this paper is very small for the application of GMM ( $n=28)$, meaning the method is inappropriate. According to Al-muharrami and Murthy (2017) and Ibrahim and Law (2019), a small sample and number of observations of $\mathrm{n}<40$ could lead to serious bias. Therefore, this paper opted for static panel data approach, as this was deemed to be appropriate. A validity test was used to select the appropriate statistical tests for the regression model. The analysis first compared the static panel data random effects and the fixed-effect models of panel analysis using the Hausman specification test (Baltagi, 2005). The results from the test indicate the appropriateness of the fixed-effects model over that of random effects, using a test of the null hypothesis based on the p-value of the chi-square. Accordingly, the static panel data employed in this study were fixed effects panel data. Diagnostic tests for the model were then performed. For example, to test for heteroscedasticity, the modified Wald statistic was used, while the Wooldrige test was run to check for autocorrelation.

\section{RESULTS AND ANALYSIS}

\subsection{Results}

Table 2 presents the descriptive statistics, including the mean, and the standard error minimum and maximum values for each of the variables incorporated in the 
model. The sample period was from 2009 to 2017. Column 2, "Obs.", denotes the number of observations, while columns 3-6 denote the mean, standard deviation, minimum and maximum respectively. The total number of observations of the 28 Islamic banks was 127. As shown in Table 2, the mean of the Islamic bank margins in the ASEAN countries was approximately 3.659\%, with the minimum and maximum levels being positive, suggesting that banks can cover their deposit interest by lending rates, resulting in a high standard deviation. Turning to the main variables, the mean and standard deviations of Islamic regulatory were 0.850 and 0.358 respectively, suggest that few countries in the ASEAN region have separate Islamic regulatory frameworks. In addition, the minimum value for Shari'ah board size was 0 and the maximum 0.3 . The values roughly explain that on average almost three Shari'ah scholars are appointed in ASEAN region countries.

Table 2.

Descriptive Statistics

\begin{tabular}{lccccc}
\hline Variable & Obs & Mean & $\begin{array}{c}\text { Std. } \\
\text { Dev. }\end{array}$ & Min & Max \\
\hline Bank Margins & 127 & 3.659 & 1.966 & -2.440 & 9.100 \\
Size & 127 & 7.721 & 1.484 & 4.260 & 10.610 \\
Risk Aversion? & 127 & 10.398 & 12.173 & -27.910 & 73.170 \\
Efficiency & 127 & 65.054 & 22.475 & 29.590 & 140.400 \\
Liquidity & 127 & 14.331 & 9.983 & 0.340 & 54.210 \\
Credit Risk & 127 & 4.013 & 6.777 & 0.470 & 41.190 \\
Lerner Index & 127 & 0.650 & 0.254 & 0.013 & 0.994 \\
GDP & 127 & 5.000 & 1.745 & -1.500 & 15.200 \\
Inflation & 127 & 3.486 & 1.787 & -0.900 & 6.400 \\
Interest Rate Risk & 127 & 0.218 & 0.252 & 0.000 & 0.882 \\
Islamic Regulatory Framework & 127 & 0.850 & 0.358 & 0.000 & 1.000 \\
Shari'ah Board & 127 & 0.331 & 0.836 & 0.000 & 3.000 \\
\hline
\end{tabular}

In addition, Table 3 shows the correlation matrix of the dependent and explanatory variables in ASEAN countries using Pearson's and Spearman's correlation matrices to test the existence of multicollinearity. According to Gujarati and Porter (2009), a correlation matrix that is less than 0.95 suggests that there is no serious multicollinearity problem. Hence, all the explanatory variables can be included in the regression. Table 3 also shows that the positive correlation matrix of the Islamic regulatory framework and Shari'ah board with bank margins potentially leads to a rise in bank margins in the ASEAN region. Similarly, almost all the bank-specific factors which could increase bank margins are shown in the correlation matrix with a positive relationship. The descriptive statistics and correlation indicate the nature of the variables and show different tendencies for different subgroups of banks. Therefore, the following section analyses the effect of these variables on bank margins through regression analysis. The data used in this study were unbalanced panel data, so panel data regression was chosen to analyse and observe the relationships between changes in the variables over time. Furthermore, the observation of the panel data consisted of cross-sectional unit 
and time-series, which were intended to provide more efficient estimates (Baltagi, 2005).

Table 3.

Pairwise Correlation Matrix for Dependent and Independent Variables for Islamic Banks

\begin{tabular}{|c|c|c|c|c|c|c|c|c|c|c|c|c|}
\hline & 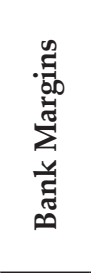 & iั & 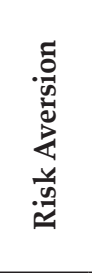 & 总 & 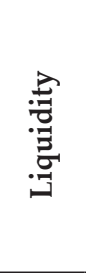 & 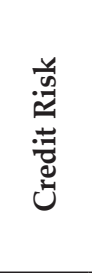 & 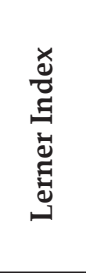 & 今ิ & 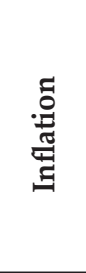 & 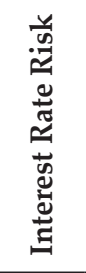 & 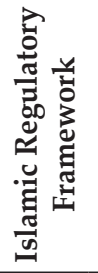 & 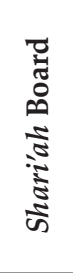 \\
\hline Bank Margins & 1 & & & & & & & & & & & \\
\hline Size & -0.313 & 1.000 & & & & & & & & & & \\
\hline Risk Aversion & 0.242 & -0.505 & 1.000 & & & & & & & & & \\
\hline $\begin{array}{l}\text { Management } \\
\text { Efficiency }\end{array}$ & 0.183 & -0.491 & -0.112 & 1.000 & & & & & & & & \\
\hline Liquidity & 0.038 & -0.295 & 0.183 & -0.065 & 1.000 & & & & & & & \\
\hline Credit Risk & 0.065 & -0.282 & 0.129 & 0.353 & 0.082 & 1.000 & & & & & & \\
\hline Lerner Index & 0.298 & -0.723 & 0.414 & 0.369 & 0.191 & 0.132 & 1.000 & & & & & \\
\hline GDP & -0.025 & -0.081 & 0.401 & -0.068 & -0.208 & -0.100 & 0.207 & 1.000 & & & & \\
\hline Inflation & 0.506 & -0.550 & 0.408 & 0.230 & 0.054 & -0.106 & 0.455 & 0.260 & 1.000 & & & \\
\hline $\begin{array}{l}\text { Interest Rate } \\
\text { Risk }\end{array}$ & 0.343 & -0.447 & 0.123 & 0.139 & 0.274 & 0.048 & 0.368 & 0.124 & 0.447 & 1.000 & & \\
\hline $\begin{array}{l}\text { Islamic } \\
\text { Regulatory } \\
\text { Framework }\end{array}$ & 0.080 & -0.105 & -0.105 & 0.227 & -0.304 & 0.023 & 0.024 & 0.034 & 0.362 & 0.044 & 1.000 & \\
\hline Shari'ah Board & 0.412 & -0.290 & 0.076 & 0.239 & 0.170 & 0.010 & 0.336 & 0.038 & 0.389 & 0.261 & 0.167 & 1.000 \\
\hline
\end{tabular}

\subsection{Baseline Regressions}

Table 4 shows the estimation results using the fixed-effects model. The Hausman test was conducted to choose the appropriate model, either fixed or random-effects. The FEM was selected since the p-value of the Hausman test was lower than $5 \%$ significance, which suggests that the null hypothesis of the random effects model being appropriate was rejected. Furthermore, robust standard errors were also applied to correct heteroscedasticity (Baltagi, 2005). Table 4 presents the estimation results for the baseline FEM specifications. The regressions in column (1) include only bank-specific factors, followed by those in columns (2) and (3), which include market-specific and macroeconomic variables. The regressions in columns (4) and (5) incorporate the main variables of interest, with regulation variables alternately in the estimations to avoid the multicollinearity problem. 
Table 4.

Fixed Effects Estimations of Islamic Regulations on Margins of Islamic Banks

\begin{tabular}{|c|c|c|c|c|c|}
\hline & (1) & (2) & (3) & (4) & (5) \\
\hline & NFM & NFM & NFM & NFM & NFM \\
\hline \multicolumn{6}{|c|}{ Bank-specific factors } \\
\hline \multirow[t]{2}{*}{ Size } & 0.6400 & 0.8111 & 1.2069 & 1.4409 & 1.2081 \\
\hline & $(0.393)$ & $(0.307)$ & $(0.175)$ & $(0.113)$ & $(0.171)$ \\
\hline Risk & 0.0006 & 0.0038 & -0.0009 & -0.0054 & 0.0050 \\
\hline Aversion & $(0.989)$ & $(0.934)$ & $(0.983)$ & $(0.905)$ & $(0.905)$ \\
\hline Management & -0.0016 & -0.0002 & 0.0033 & 0.0027 & 0.0043 \\
\hline Efficiency & $(0.942)$ & $(0.993)$ & $(0.880)$ & $(0.899)$ & $(0.845)$ \\
\hline \multirow[t]{2}{*}{ Liquidity } & -0.0075 & -0.0056 & -0.0024 & -0.0104 & -0.0053 \\
\hline & $(0.773)$ & $(0.832)$ & $(0.932)$ & $(0.723)$ & $(0.850)$ \\
\hline Credit & -0.0074 & -0.0040 & 0.0065 & 0.0066 & 0.0042 \\
\hline Risk & $(0.579)$ & $(0.738)$ & $(0.704)$ & $(0.674)$ & $(0.806)$ \\
\hline \multicolumn{6}{|c|}{ Market-specific factors } \\
\hline Lerner & & 0.5772 & $0.8923^{* *}$ & $0.7289^{* *}$ & $0.8477^{4 *}$ \\
\hline Index & & $(0.165)$ & $(0.027)$ & $(0.033)$ & $(0.032)$ \\
\hline \multicolumn{6}{|c|}{ Macroeconomic factors } \\
\hline \multirow[t]{2}{*}{ GDP } & & & -0.0967 & -0.1093 & -0.1009 \\
\hline & & & $(0.169)$ & $(0.132)$ & $(0.145)$ \\
\hline \multirow[t]{2}{*}{ Inflation } & & & 0.1691 & 0.1847 & 0.1344 \\
\hline & & & $(0.139)$ & $(0.106)$ & $(0.238)$ \\
\hline Interest & & & 0.4950 & 0.5238 & 0.6263 \\
\hline Rate Risk & & & $(0.332)$ & $(0.294)$ & $(0.232)$ \\
\hline \multicolumn{6}{|c|}{ Regulatory factors } \\
\hline Islamic & & & & $-0.8416^{*+*}$ & \\
\hline Regulatory & & & & $(0.036)$ & \\
\hline \multicolumn{6}{|l|}{ Framework } \\
\hline Shari'ah & & & & & $-1.0486^{6+1+}$ \\
\hline Board & & & & & $(0.000)$ \\
\hline \multirow[t]{2}{*}{ _cons } & -1.0457 & -2.9097 & -6.6526 & -7.4360 & -6.2472 \\
\hline & $(0.878)$ & $(0.692)$ & $(0.378)$ & $(0.298)$ & $(0.400)$ \\
\hline$N$ & 127 & 127 & 127 & 127 & 127 \\
\hline No. of Groups & 28 & 28 & 28 & 28 & 28 \\
\hline R-squared & 0.0395 & 0.0470 & 0.1112 & 0.1630 & 0.1521 \\
\hline
\end{tabular}

The results show that the Islamic regulatory framework has a negative effect on bank margins, which supports the public interest theory. The negatively significant impact on bank margins demonstrates that the separate regulatory framework for Islamic banks in ASEAN countries introduced by the government is an essential factor in reducing bank margins, as it helps to improve social welfare. However, the results contradict the empirical evidence of Alam et al. (2018). This is because a separate regulatory framework for Islamic banks would be able to cater for the differences between Islamic banks and Islamic banking product theory and practice. For instance, the framework possibly analyses the products marketed 
by Islamic banks to confirm their Sharī ah compliance. Moreover, a regulatory framework specifically designed for Islamic banks could overcome the displaced commercial risk resulting from higher rates of return on investment accounts suffered by Islamic banks. The reduction in risk in Islamic banks would enhance investment activities, thereby lowering the cost of intermediation. Therefore, an Islamic regulatory framework in Islamic banks could address the shortcomings of the contracts utilised by them. In other words, an appropriate set of regulations for Islamic banks could help to lower the cost of intermediation.

Only Malaysia and Indonesia issue separate guidelines and regulations specific to Islamic banks. The regulations in these countries provide a framework that governs industry practice, covers the duties and responsibilities held by stakeholders, and provides details on processes and procedures in Islamic bank operations that are consistent with Shari'ah compliance. Malaysian Islamic banks are regulated and supervised by the Islamic Financial Services Act 2013 (IFSA), while those in Indonesia are supervised by Banking Act No. 21. Interestingly, one of the features of the IFSA act is to ensure that deposits in Islamic banks are placed in investment accounts, as s process of channeling funds (Bank Negara Malaysia, 2013; Budiman et al., 2019). This feature requires the banks to disclose the sources of their funds, the structuring of investment account products, and profit distribution. The disclosure of funds by Islamic banks could provide precise information regarding financial statements, which is essential for shareholders and depositors when investing in banks. Thereby, banks would lower the costs charged to borrowers in response to high investment levels from depositors and shareholders.

Similarly, the second variable is that the Shari'ah supervisory board also has a negative and significant influence on Islamic bank margins in ASEAN countries. The results imply that a high number of Shari'ah scholars on Shari'ah supervisory boards in Islamic banks will reduce bank margins, which indicates that Islamic banks' governance characteristics are one of the criteria for studying the impact of Islamic regulation on bank margins. Correspondingly, the estimation results show that the number of Shari'ah scholars in Islamic banks in ASEAN countries, according to governance standards, could help impose appropriate regulations that could lower Islamic bank margins, leading to a significantly negative impact on such margins at the $1 \%$ level. A plausible explanation for this would be that Shari'ah scholars on Shari'ah supervisory boards ensure that the products and services related to Islamic bank activities are Shari'ah compliant. Therefore, this will create trust among borrowers towards Islamic banks, depositors would not withdraw deposits, and investors would not cancel investment agreements, which would lower the cost of intermediation. The Shari'ah supervisory board is a committee in Islamic banks' governance structure that is responsible for reviewing and approving the products offered by Islamic banks; they play a major role in influencing investors and depositors. As indicated by Aljifri and Khandelwal (2013), the monitoring of banks' internal information by the Shari'ah supervisory board created trust amongst investors regarding Islamic banks management. This is because Shari'ah requirements in the IFSA act stipulate that banks are required to provide accurate and complete information to the board committee (Bank Negara Malaysia, 2013). Furthermore, Meslier et al. (2020) found that having many experts 
on Shari'ah supervisory boards would reduce agency costs and effectively monitor bank managers. This monitoring could ensure that banks are not misled by corruption in bank lending, thereby improving their function as intermediaries.

Regarding the control variables, only the market-specific variable measured by the Lerner index has a significant impact on Islamic bank margins in the ASEAN region. The indicator is positive and significant at the $5 \%$ level, in line with the expected sign. This positive and significant result possibly explains how an increase in the Lerner index ratio reflects greater market power amongst banks (low competition), allowing them to charge high loan rates and low deposit rates, thereby increasing bank margins. The finding is similar to that of Trinugroho et al. (2018), which showed that Islamic rural banks in Indonesia were experiencing higher margins due to their high market power.

\subsection{Robustness Test}

Several sets of robustness checks were conducted on the baseline results. First, different net financing margin measurements were incorporated (the difference between the implicit lending rate and the implicit deposit rate) as alternative measurements. Second, acknowledging that the major Islamic banks in ASEAN countries are in Malaysian and Indonesia, this paper implies a sample consisting only of Malaysia and Indonesia. Third, we excluded Islamic banks from the sample to focus specifically on the effect of Islamic banking presence on conventional banks' intermediation costs. Finally, we employed an alternative method of estimation, namely the GMM panel. The results of these robustness checks are shown in Tables 5 to 7.

Table 5 shows the robustness check results using the different measurements of the dependent variable, which is the difference between the implicit lending rate and deposit rate. The lending rate was calculated as the ratio of interest income on loans divided by total loans, while the implicit deposit rate was computed as the ratio of interest expenses on customer deposits divided by total deposits.

Table 5.

Robustness Checks: Fixed Effect Sestimations of Islamic Regulations on the Bank Margins of Islamic Banks

\begin{tabular}{lccccc}
\hline & $\mathbf{( 1 )}$ & $\mathbf{( 2 )}$ & $\mathbf{( 3 )}$ & $\mathbf{( 4 )}$ & $\mathbf{( 5 )}$ \\
\hline & NFM & NFM & NFM & NFM & NFM \\
\hline Bank-specific factors & & & & & \\
Size & $1.8073^{*}$ & $2.1872^{*}$ & $2.7213^{* *}$ & $2.9354^{* *}$ & $2.7236^{* *}$ \\
& $(0.091)$ & $(0.069)$ & $(0.018)$ & $(0.010)$ & $(0.015)$ \\
Risk & -0.0360 & -0.0290 & -0.0317 & -0.0358 & -0.0204 \\
Aversion & $(0.543)$ & $(0.630)$ & $(0.600)$ & $(0.585)$ & $(0.728)$ \\
Quality of & 0.0120 & 0.0152 & 0.0182 & 0.0177 & 0.0201 \\
Management & $(0.645)$ & $(0.564)$ & $(0.533)$ & $(0.558)$ & $(0.489)$ \\
Liquidity & -0.0143 & -0.0099 & -0.0065 & -0.0138 & -0.0120 \\
& $(0.642)$ & $(0.744)$ & $(0.829)$ & $(0.687)$ & $(0.671)$ \\
Credit & $-0.0396^{*}$ & -0.0319 & -0.0196 & -0.0194 & -0.0239 \\
\hline
\end{tabular}


Table 5.

Robustness Checks: Fixed Effect Sestimations of Islamic Regulations on the Bank Margins of Islamic Banks

\begin{tabular}{|c|c|c|c|c|c|}
\hline & (1) & (2) & (3) & (4) & (5) \\
\hline & NFM & NFM & NFM & NFM & NFM \\
\hline Risk & $(0.080)$ & (0.153) & $(0.411)$ & $(0.385)$ & $(0.307)$ \\
\hline \multicolumn{6}{|c|}{ Market-specific factors } \\
\hline Lerner & & $1.2815^{*}$ & $1.8227^{* * *}$ & $1.6732^{* *}$ & $1.7378^{* *}$ \\
\hline Index & & $(0.077)$ & $(0.022)$ & $(0.021)$ & $(0.021)$ \\
\hline \multicolumn{6}{|c|}{ Macroeconomic variables } \\
\hline \multirow[t]{2}{*}{ GDP } & & & $-0.1930^{* *}$ & $-0.2045^{* *}$ & $-0.2010^{* *}$ \\
\hline & & & $(0.018)$ & $(0.017)$ & $(0.014)$ \\
\hline \multirow[t]{2}{*}{ Inflation } & & & 0.2255 & 0.2397 & 0.1593 \\
\hline & & & $(0.132)$ & $(0.112)$ & $(0.160)$ \\
\hline Interest & & & 0.3043 & 0.3306 & 0.5541 \\
\hline Rate Risk & & & $(0.746)$ & $(0.720)$ & $(0.566)$ \\
\hline \multicolumn{6}{|l|}{ Regulatory factors } \\
\hline Islamic & & & & -0.7700 & \\
\hline Regulatory & & & & $(0.147)$ & \\
\hline \multicolumn{6}{|l|}{ Framework } \\
\hline Shari'ah & & & & & $-1.9956^{*+4+4}$ \\
\hline Board & & & & & $(0.000)$ \\
\hline \multirow{2}{*}{ _cons } & -10.4239 & -14.5628 & $-19.1915^{* *}$ & $-19.9082^{* *}$ & $-18.4200^{* * x}$ \\
\hline & $(0.222)$ & $(0.147)$ & $(0.042)$ & $(0.025)$ & $(0.046)$ \\
\hline$N$ & 127 & 127 & 127 & 127 & 127 \\
\hline No. of Groups & 28 & 28 & 28 & 28 & 28 \\
\hline R-squared & 0.1007 & 0.1146 & 0.1703 & 0.1866 & 0.2260 \\
\hline
\end{tabular}

From Table 5, it can be observed that the role of the Shari'ah board in Islamic bank margins had similar results as the baseline regression, which negative and significant at $1 \%$. However, the Islamic regulatory results became insignificant when tested using the different measurements of the dependent variable. This could be explained by the different set of regulatory frameworks for Islamic banks that do not influence their implicit deposit and lending rates in the ASEAN region. The Lerner Index variable in the robustness check also provides similar reasoning as the baseline regression. Interestingly, the macroeconomic variable, GDP growth, is negative and significant at the 5\% level throughout all the models tested. GDP growth could help to lower the lending rate by increasing the deposit rates. Similarly, the logarithm of total assets, which is a proxy for bank size, shows a significant but positive influence on bank margins. This positively significant finding could explain the fact that larger Islamic bank assets will increase lending rates and reduce deposit rates, thereby reducing bank margins. However, the finding contradicts several studies (Chortareas et al., 2012; Noman et al., 2018; Ibrahim, 2019). According to Ibrahim and Rizvi (2017), larger banks will not depend on deposit rates as sources of funds, because of their alternative sources of funds. 
Table 6 shows the estimation results using an alternative estimator, GMM. It illustrates that the lagged dependent variable (L.nfm) is not significant at either the $1 \%$ or $5 \%$ level in most regression models. The insignificant results suggest that the specification of this model is not dynamic. Therefore, the estimations via the GMM method were not appropriate for testing the baseline regression, which supports the baseline regression on applying static panel data.

Table 6.

Robustness: Alternative Estimators

\begin{tabular}{|c|c|c|c|c|c|}
\hline & (1) & (2) & (3) & (4) & (5) \\
\hline & NFM & NFM & NFM & NFM & NFM \\
\hline \multirow[t]{2}{*}{ L.nfm } & -0.0882 & -0.0741 & -0.0756 & $-0.1345^{*}$ & -0.1163 \\
\hline & $(0.493)$ & $(0.551)$ & $(0.384)$ & $(0.071)$ & $(0.261)$ \\
\hline \multicolumn{6}{|c|}{ Bank-specific factors } \\
\hline \multirow[t]{2}{*}{ Size } & -0.4899 & -0.3591 & -0.1508 & -0.1525 & -0.1641 \\
\hline & $(0.160)$ & $(0.319)$ & $(0.696)$ & $(0.683)$ & $(0.745)$ \\
\hline Risk & -0.0183 & -0.0188 & -0.0411 & -0.0394 & -0.0372 \\
\hline Aversion & $(0.515)$ & $(0.482)$ & $(0.228)$ & $(0.260)$ & $(0.305)$ \\
\hline Management & $-0.0284^{* * * *}$ & $-0.0302^{* * *}$ & $-0.0336^{* * 4}$ & $-0.0319^{* * * *}$ & $-0.0327^{* * *}$ \\
\hline Efficiency & $(0.000)$ & $(0.000)$ & $(0.000)$ & $(0.000)$ & $(0.000)$ \\
\hline \multirow[t]{2}{*}{ Liquidity } & $0.0119^{* * *}$ & $0.0128^{* *}$ & $0.0205^{* * *}$ & $0.0215^{* * *}$ & $0.0202^{* * *}$ \\
\hline & $(0.021)$ & $(0.021)$ & $(0.003)$ & $(0.000)$ & $(0.030)$ \\
\hline Credit & $-0.0251^{* * * * *}$ & $-0.0236^{* * * *}$ & $-0.0154^{* *}$ & $-0.0133^{* *}$ & $-0.0147^{* * *}$ \\
\hline Risk & $(0.001)$ & $(0.000)$ & $(0.013)$ & $(0.012)$ & $(0.013)$ \\
\hline \multicolumn{6}{|c|}{ Market-specific factors } \\
\hline Lerner & & 0.1841 & 0.3564 & $0.3773^{*}$ & 0.3610 \\
\hline Index & & $(0.425)$ & $(0.135)$ & $(0.071)$ & $(0.185)$ \\
\hline \multicolumn{6}{|l|}{$\begin{array}{l}\text { Macroeconomic } \\
\text { factors }\end{array}$} \\
\hline \multirow[t]{2}{*}{ GDP } & & & -0.0155 & -0.0118 & -0.0084 \\
\hline & & & $(0.811)$ & $(0.869)$ & $(0.903)$ \\
\hline \multirow[t]{2}{*}{ Inflation } & & & $0.0835^{* *}$ & $0.0876^{* *}$ & $0.0824^{*}$ \\
\hline & & & $(0.047)$ & $(0.031)$ & $(0.077)$ \\
\hline Interest & & & 0.3501 & 0.3387 & 0.3680 \\
\hline Rate Risk & & & $(0.174)$ & $(0.188)$ & $(0.239)$ \\
\hline \multicolumn{6}{|c|}{ Regulatory factors } \\
\hline Islamic & & & & -0.1478 & \\
\hline Regulatory & & & & $(0.627)$ & \\
\hline \multicolumn{6}{|l|}{ Framework } \\
\hline Shari'ah & & & & & $-0.6938^{* * *}$ \\
\hline Board & & & & & $(0.002)$ \\
\hline \multirow[t]{2}{*}{ _cons } & $9.4592^{* * *}$ & $8.3121^{* * * *}$ & $6.4633^{* *}$ & $6.6211^{* * *}$ & $6.8409^{*}$ \\
\hline & $(0.000)$ & $(0.004)$ & $(0.020)$ & $(0.009)$ & $(0.072)$ \\
\hline$N$ & 99 & 99 & 99 & 99 & 99 \\
\hline No. of Groups & 26 & 26 & 26 & 26 & 26 \\
\hline Hansen Test & 3.1507 & 3.1674 & 3.5799 & 3.4640 & 3.1175 \\
\hline
\end{tabular}


Table 6.

Robustness: Alternative Estimators (Continued)

\begin{tabular}{lccccc}
\hline & $\mathbf{( 1 )}$ & $\mathbf{( 2 )}$ & $\mathbf{( 3 )}$ & $\mathbf{( 4 )}$ & $\mathbf{( 5 )}$ \\
\hline & $\mathbf{N F M}$ & $\mathbf{N F M}$ & $\mathbf{N F M}$ & $\mathbf{N F M}$ & $\mathbf{N F M}$ \\
\hline p-value $)$ & $(0.7897)$ & $(0.7876)$ & $(0.7333)$ & $(0.7488)$ & $(0.7940)$ \\
AR1 & -0.9268 & -0.9187 & -0.9303 & -0.9735 & -1.0009 \\
$(p$-value $)$ & $(0.3540)$ & $(0.3583)$ & $(0.3522)$ & $(0.3303)$ & $(0.3169)$ \\
AR2 & 0.9478 & 0.9399 & 1.1127 & 1.1945 & 1.6185 \\
$(p$-value $)$ & $(0.3432)$ & $(0.3473)$ & $(0.2658)$ & $(0.2323)$ & $(0.1056)$ \\
No. of Instruments & 13 & 14 & 17 & 18 & 18 \\
\hline
\end{tabular}

Finally, Table 7 presents the findings on the effect of Islamic regulations on Malaysian and Indonesian banks margins, which are the main Islamic banks in the ASEAN region. The results of the main variables, that is, the separate regulatory framework for Islamic banks and the Shari'ah board for regulation purposes on bank margins, are negative and significant at the $5 \%$ level, which is consistent with the main regression results. An explanation for this would be that countries with already naturally imposed regulations to fit Islamic bank operations, with regulations that follow Shari'ah principles, result in low bank margin levels. For example, Malaysia implements regulations according to the Islamic Banking Act 1983 and the Islamic Financial Services Act 2013, whereas Indonesia follows Law Number 21 of 2008 for Islamic banking regulation. In other words, to enhance Islamic bank efficiency, an appropriate set of regulations must be in place. The same goes for the Shari'ah board; an appropriate board member would reduce the cost of intermediation.

Table 7.

Robustness Test: Split Sample

\begin{tabular}{lccccc}
\hline & $\mathbf{( 1 )}$ & $\mathbf{( 2 )}$ & $\mathbf{( 3 )}$ & $\mathbf{( 4 )}$ & $\mathbf{( 5 )}$ \\
\hline & $\mathbf{N F M}$ & $\mathbf{N F M}$ & $\mathbf{N F M}$ & $\mathbf{N F M}$ & NFM \\
\hline Bank-specific factors & & & & & \\
Size & 0.2324 & 0.3396 & 0.8897 & $1.1477^{*}$ & $0.9255^{*}$ \\
& $(0.660)$ & $(0.539)$ & $(0.107)$ & $(0.055)$ & $(0.093)$ \\
Risk & $-0.2222^{* *}$ & $-0.2243^{* *}$ & $-0.2018^{* *}$ & $-0.1835^{*}$ & -0.1821 \\
Aversion & $(0.030)$ & $(0.030)$ & $(0.050)$ & $(0.053)$ & $(0.100)$ \\
Quality of & -0.0016 & -0.0008 & 0.0047 & 0.0047 & 0.0055 \\
Management & $(0.936)$ & $(0.968)$ & $(0.805)$ & $(0.806)$ & $(0.774)$ \\
Liquidity & -0.0025 & -0.0010 & 0.0023 & -0.0041 & 0.0003 \\
& $(0.891)$ & $(0.956)$ & $(0.911)$ & $(0.845)$ & $(0.989)$ \\
Credit & 0.0069 & 0.0082 & 0.0178 & 0.0183 & 0.0157 \\
Risk & $(0.658)$ & $(0.601)$ & $(0.404)$ & $(0.363)$ & $(0.471)$ \\
Market-specific factors & & & & & \\
Lerner & & 0.5041 & $0.8260^{* *}$ & $0.6251^{*}$ & $0.7873^{*}$ \\
Index & & $(0.229)$ & $(0.040)$ & $(0.067)$ & $(0.056)$ \\
\hline
\end{tabular}


Table 7.

Robustness Test: Split Sample

\begin{tabular}{lccccc}
\hline & $\mathbf{( 1 )}$ & $\mathbf{( 2 )}$ & $\mathbf{( 3 )}$ & $\mathbf{( 4 )}$ & $\mathbf{( 5 )}$ \\
\hline & NFM & NFM & NFM & NFM & NFM \\
\hline Macroeconomic factors & & & & & \\
GDP & & $-0.1295^{* *}$ & $-0.1471^{* *}$ & $-0.1335^{* *}$ \\
& & $(0.004)$ & $(0.002)$ & $(0.003)$ \\
Inflation & & 0.1435 & 0.1663 & 0.1244 \\
& & $(0.286)$ & $(0.211)$ & $(0.373)$ \\
Interest & & 0.6765 & 0.6800 & 0.7465 \\
Rate Risk & & $(0.219)$ & $(0.200)$ & $(0.176)$ \\
Regulatory factors & & & & \\
Islamic & & & $-0.6836^{* *}$ & \\
Regulatory & & & $(0.042)$ & \\
Framework & & & & \\
Shari'ah & & & & $-0.6828^{* *}$ \\
Board & & & & $(0.006)$ \\
cons & & & & & -2.1024 \\
& & & & & \\
\hline$N$ & 3.1897 & -1.9459 & $0.641)$ \\
\hline No. of Groups & 26.0000 & 26.0000 & 26.0000 & 26.0000 & 26.0000 \\
R-squared & 0.1612 & 0.1660 & 0.2217 & 0.2568 & 0.2397 \\
\hline
\end{tabular}

\section{CONCLUSION AND RECOMMENDATIONS}

\subsection{Conclusion}

This paper has analysed the impact of Islamic regulations on the margins of Islamic banks in ASEAN countries. The method employ in the study was a fixed effects estimator on a panel dataset of 27 Islamic banks, covering the period 2009 to 2017 in four ASEAN countries (Malaysia, Indonesia, Singapore and Thailand). The results suggest the important role of the Islamic regulatory framework and the Shari'ah board in lowering Islamic bank margins and intermediation costs. Therefore, countries without an Islamic regulatory framework could consider implementing a separate regulatory framework suitable for Islamic banks. Similarly, the number of Shari'ah scholars on the Shari'ah board plays a significant role in reducing bank margins.

\subsection{Recommendations}

Policy implications for bank managers include improving Shari'ah scholars' credibility to supervise banks better, thereby attracting more investors and reducing the cost of intermediation. The credibility of Shari'ah board members will also ensure the confidence of stakeholders and the public. Furthermore, appropriate Shari'ah board members allocated to bank supervision will enable shareholders and investors to have better updates regarding their investments and possible risk.

With regard to regulators, they need to ensure that Islamic banks are governed by Islamic regulatory organisations such as the Islamic Financial Services Board 
and the Accounting and Auditing Organization for Islamic Financial Institutions. Moreover, countries that do not yet specify a separate regulatory framework for Islamic banks could consider implementing one, as they reduce the cost of intermediation. Moreover, bank managers could consider appropriate policies to foster competition, which would result in less market power, thus allowing the consolidation of Islamic banks by setting higher prices for their products.

The paper is also subject to limitations, such as the small number of Islamic banks studied. Future research could include a greater number of banks in order to understand the Islamic banking system's behavior better. Moreover, future research also could compare the regulatory frameworks of Islamic banks in different countries. In addition, the paper only examined the Shari'ah supervisory board effect on Islamic bank margins, without considering the board members' characteristics. Therefore, future research could elaborate on the board member criteria to provide insights into their role.

\section{REFERENCES}

Al-muharrami, S., \& Murthy, Y. S. R. (2017). Interest banking spreads in Oman and Arab GCC. International Journal of Emerging Markets, 12(3), 532-549.

Alam, N. (2012). The impact of regulatory and supervisory structures on bank risk and efficiency: Evidence from dual banking system. Asian Journal of Finance $\mathcal{E}$ Accounting, 4(1), 216-244.

Alam, N. (2013). Impact of banking regulation on risk and efficiency in Islamic banking. Journal of Financial Reporting and Accounting, 11(1), 29-50.

Alam, N. (2014). Regulations and bank risk taking in dual banking countries. Journal of Banking Regulation, 15(2), 105-116.

Alam, N., Zainuddin, S. S., \& Rizvi, S. A. R. (2018). Ramifications of varying banking regulations on performance of Islamic Banks. Borsa Istanbul Review, 19(1), 49-64.

Alexakis, C., \& Tsikouras, A. (2009). Islamic finance: Regulatory framework challenges lying ahead. International Journal of Islamic and Middle Eastern Finance and Management, 2(2), 90-104.

Aljifri, K., \& Khandelwal, S. K. (2013). Financial contracts in conventional and Islamic financial institutions: An agency theory perspective. Review of Business and Finance Studies, 4(2), 79-89.

Allen, L. (1988). The Determinants of Bank Interest Margins: A Note. The Journal of Financial and Quantitative Analysis, 23(2), 231-235.

Alsartawi, A. M. (2019). Performance of Islamic banks: Do the frequency of Sharī' ah supervisory board meeting and independence matter?. ISRA International Journal of Islamic Finance, 11(2), 303-321.

Angbazo, L. (1997). Commercial bank net interest margins, default risk, interestrate risk, and off-balance sheet banking. Journal of Banking and Finance, 21(1), 55-87.

Apaydin, F. (2018). Regulating Islamic banks in authoritarian settings: Malaysia and the United Arab Emirates in comparative perspective. Regulation $\mathcal{E}$ Governance, 12(May), 466-485. 
Ascarya, A., \& Yumanita, D. (2010). Determinants of bank's net interest margin in Indonesia. International Conference On Eurasian Economies 2010, 252-257.

Baltagi, B. H. (2005). Econometric analysis of panel data (3rd Edition). New York: John Wiley \& Sons Inc.

Bank Negara Malaysia. (2013). Islamic Financial Services Act 2013. Islamic Financial Services Act 2013. Retrieved from http://www.bnm.gov.my/documents/act/ en_ifsa.pdf

Barth, J. R., Caprio Jr., G., \& Levine, R. (2006). Banking systems around the globe: Do regulation and ownership affect performance and stability? Cato Journal, 26.

Barth, J. R., Caprio Jr., G., \& Levine, R. (2013). Bank regulation and supervision in 180 countries from 1999 to 2011 (Working Paper 18733 No. Working Paper 18733). Retrieved from http://www.nber.org/papers/w18733

Beck, T., \& Hesse, H. (2009). Why are interest spreads so high in Uganda? Journal of Development Economics, 88(2), 192-204. https://doi.org/10.1016/j. jdeveco.2008.07.004

Birchwood, A., Brei, M., \& Noel, D. (2017). Interest margins and bank regulation in Central America and the Caribbean. Journal of Banking \& Finance, 85, 56-68.

Bitar, M., Kabir, M., Pukthuanthong, K., \& Walker, T. (2018). The performance of Islamic vs. conventional banks: Evidence on the suitability of the Basel capital ratios. Open Economies Review, 29, 1003-1038.

Bougatef, K., \& Korbi, F. (2018). The determinants of intermediation margins in Islamic and conventional banks. Managerial Finance, 44(6), 704-721.

Boukhatem, J., \& Moussa, F. Ben. (2018). The effect of Islamic banks on GDP growth: Some evidence from selected MENA countries. Borsa Istanbul Review, 18(3), 231-247.

Bourkhis, K., \& Nabi, M. S. (2011). Have Islamic banks been more resistant than conventional banks to the 2007-2008 Financial Crisis? The Economic Research Forum, 616, 1-27.

Brock, P. L., \& Rojas Suarez, L. (2000). Understanding the behavior of bank spreads in Latin America. Journal of Development Economics, 63(1), 113-134.

Buffet, M. (2016). How do CDOs and CDSs influence the crisis of 2008. Lingnan Journal of Banking, Finance and Economics, 6(1).

Carbó Valverde, S., \& Rodríguez Fernández, F. (2007). The determinants of bank margins in European banking. Journal of Banking and Finance, 31(7), 2043-2063.

Chortareas, G. E., Girardone, C., \& Ventouri, A. (2012). Bank supervision, regulation, and efficiency: Evidence from the European Union. Journal of Financial Stability, 8(4), 292-302.

Cruz-García, P., \& Fernández De Guevara, J. (2019). Determinants of net interest margin: The effect of capital requirements and deposit insurance scheme. The European Journal of Finance, 4364.

Dar, H. A., \& Presley, J. R. (2000). Lack of profit loss sharing in Islamic banking: Management and control imbalances. International Journal of Islamic Financial Services, 2(2), 3-18.

Demirguc-Kunt, A., Laeven, L., \& Levine, R. (2004). Regulations, market structure, institutions, and the cost of financial intermediation. Journal of Money, Credit, and Banking, 36(3b), 593-622. 
Drakos, K. (2003). Assessing the success of reform in transition banking 10 years later : An interest margins analysis. Journal of Policy Modeling, 25(3), 309-317.

Entrop, O., Memmel, C., Ruprecht, B., \& Wilkens, M. (2015). Determinants of bank interest margins: Impact of maturity transformation. Journal of Banking and Finance, 54(June), 1-19.

Gelos, R. G. (2006). Banking Spreads in Latin America. IMF Working Paper.

Grassa, R. (2013). Shari'ah Governance system in Islamic financial institutions: new issues and challenges - A comparative analysis between Southeast Asia models and GCC models. Humanomics, 29(4), 333-348.

Gujarati, D. N., \& Porter, D. C. (2009). Essentials of econometrics (Fourth Edition). New York: McGraw-Hill Irwin.

Hamza, H. (2013). Sharia governance in Islamic banks: Effectiveness and supervision model. International Journal of Islamic and Middle Eastern Finance and Management, 6(3), 226-237. https://doi.org/10.1108/IMEFM-02-2013-0021

Haque, F., \& Brown, K. (2017). Bank ownership, regulation and efficiency: Perspectives from the Middle East and North Africa (MENA). International Review of Economics and Finance, 47, 273-293.

Hasan, M., \& Dridi, J. (2010). The Effects of the global crisis on Islamic and conventional banks: A comparative study (Working Paper No. 10/201). IMF Working Paper (Vol. 02). https://doi.org/10.1142/S1793993311000270

Hassan, M. K., Brodmann, J., \& Rayfield, B. (2017). The current status of Islamic bank regulation in the world. Journal of Islamic Economics, Banking and Finance, 13(1), 13-23.

Ho, T. S. Y., \& Saunders, A. (1981). The determinants of bank interest margins: theory and empirical evidence. Journal of Financial and Quantitative Analysis, 16(04), 581-600.

Ibrahim, M. H. (2019). Capital regulation and Islamic banking performance: Panel evidence. Buletin Ekonomi Moneter dan Perbankan, 22(1), 47-67.

Ibrahim, M. H., \& Law, S. H. (2019). Financial intermediation cost in dual banking system: The role of Islamic banking. Bulletin of Monetary Economics and Banking, 22(4), 529-550.

Ibrahim, M. H., \& Rizvi, S. A. R. (2017). Bank lending, deposits and risk-taking in times of crisis: A panel analysis of Islamic and conventional banks. Emerging Markets Review, 35, 31-47.

Ibrahim, M. H., Salim, K., Abojeib, M., \& Yeap, L. W. (2018). Structural changes, competition and bank stability in Malaysia's dual banking system. Economic Systems, 43(1), 111-129.

Kale, S., Eken, M. H., \& Selimler, H. (2015). The effects of regulations on the performance of banks: Evidence from the Turkish banking industry. Journal of Centrum Cathedra, 8(2), 109-145.

Lee, C.-S., \& Park, C. (2009). Beyond the crisis: Financial regulatory reform in emerging Asia (ADB Working Paper Series on Regional Economic Integration No.34).

Lee, S. P., \& Isa, M. (2017). Determinants of bank margins in a dual banking system. Managerial Finance, 43(6), MF-07-2016-0189.

Maudos, J., \& Fernández De Guevara, J. (2004). Factors explaining the interest margin in the banking sector of the European Union. Journal of Banking and Finance, 28, 2259-2281. 
Maudos, J., \& Solís, L. (2009). The determinants of net interest income in the Mexican banking system: An integrated model. Journal of Banking and Finance, 33(10), 1920-1931. https://doi.org/10.1016/j.jbankfin.2009.04.012

McShane, R. W., \& Sharpe, I. G. (1985). A time series/cross section analysis of the determinants of Australian trading bank loan/deposit interest margins: 19621981. Journal of Banking and Finance, 9(1), 115-136.

Meslier, C., Risfandy, T., \& Tarazi, A. (2017). Dual market competition and deposit rate setting in Islamic and conventional banks. Economic Modelling, 63(February), 318-333.

Meslier, C., Risfandy, T., \& Tarazi, A. (2020). Islamic banks' equity financing, Shariah supervisory board, and banking environments. Pacific-Basin Finance Journal, 62, 101354.

Mohd Noor, N. H. H., Bakri, M. H., Wan Yusof, W. Y. R., Mohd Noor, N. R. A., \& Zainal, N. (2020). The Impact of the Bank Regulation and Supervision on the Efficiency of Islamic Banks. Journal of Islamic Accounting and Business Research, 7(11), 747-757.

Mollah, S., \& Zaman, M. (2015). Shari'ah supervision, corporate governance and performance: Conventional vs. Islamic banks. Journal of Banking Finance, 58, 418-435.

Naceur, S. Ben, \& Omran, M. (2011). The effects of bank regulations, competition, and financial reforms on banks' performance. Emerging Markets Review, 12(1), 1-20.

Nguyen, J. (2012). The relationship between net interest margin and noninterest income using a system estimation approach. Journal of Banking and Finance, 36(9), 2429-2437.

Noman, A. H., Gee, C. S., \& Isa, C. R. (2018). Does bank regulation matter on the relationship between competition and financial stability? Evidence from Southeast Asian countries. Pacific-Basin Finance Journal, 48, 144-161.

Olson, D., \& Zoubi, T. (2017). Convergence in bank performance for commercial and Islamic banks during and after the global financial crisis. The Quarterly Review of Economics and Finance, 65, 71-87.

Peltzman, S. (1976). Toward a more general theory of regulation. The Journal of Law and Economics, 19(2), 211-240.

Poghosyan, T. (2013). Financial intermediation costs in low income countries: The role of regulatory, institutional, and macroeconomic factors. Economic Systems, $37(1), 92-110$.

Psillaki, P., \& Mamatzakis, E. (2017). What drives bank performance in transition economies? The Impact of reforms and regulations. Research in International Business and Finance, 39(PA), 578-594.

Rahman, M. M., Zheng, C., Ashraf, B. N., \& Rahman, M. M. (2017). Capital requirements, the cost of financial intermediation and bank risk-taking: Empirical evidence from Bangladesh. Research in International Business and Finance, 44, 488-503.

Saunders, A., \& Schumacher, L. (2000). The determinants of bank interest rate margins : An international study. Departement of Finance Working Paper Series 1998, 813-832. 
Solé, J. (2007). Introducing Islamic Banks into Conventional Banking Systems (IMF Working Paper No. WP/07/175). Retrieved from http://www.imf.org/external/ pubs/ft/wp/2007/wp07175.pdf

Song, I., \& Oosthuizen, C. (2014). Islamic Banking Regulation and Supervision: Survey Results and Challenges. International Monetary Fund. https://doi. org/10.5089/9781498380928.001

Stigler, G. J. (1971). The theory of economic regulation. The Bell Journal of Economics and Management Science, 2(1), 3-21.

Tongurai, J., \& Vithessonthi, C. (2020). Bank regulations, bank competition and bank risk-taking: Evidence from Japan. Journal of Multinational Financial Management, 56, 100638.

Toumi, K., Viviani, J., \& Chayeh, Z. (2018). Measurement of the displaced commercial risk in Islamic banks. Quarterly Review of Economics and Finance, 74. https://doi.org/10.1016/j.qref.2018.03.001

Trinugroho, I., Agusman, A., \& Tarazi, A. (2014). Why have bank interest margins been so high in Indonesia since The 1997/1998 Financial Crisis? Research in International Business and Finance, 32, 139-158.

Trinugroho, I., Risfandy, T., \& Ariefianto, M. D. (2018). Competition, diversification, and bank margins: Evidence from Indonesian Islamic rural banks. Borsa Istanbul Review, 18(4), 349-358.

Wan Ibrahim, W. H., \& Ismail, A. G. (2020). Do regulation, maqasid Shariah and institutional parameter improve Islamic bank efficiency? Journal of Islamic Monetary Economics and Finance, 6(1), 135-162.

Williams, B., \& Prather, L. (2010). Bank risk and return: The impact of bank noninterest income. International Journal of Managerial Finance, 6(3), 220-244.

Yanikkaya, H., Gumus, N., \& Pabuccu, Y. U. (2018). How profitability differs between conventional and Islamic banks: A dynamic panel data approach. Pacific-Basin Finance Journal, 48(July 2017), 99-111. 
This page is intentionally left blank 